\title{
The Discipline of Verification in a News Production Process (News Coverage of the Polemic of the Malaysian National Anthem in Indonesian Mass Media)
}

\author{
Bonaventura Satya Bharata ${ }^{1}$, Nik Norma Nik Hasan ${ }^{2}$ \\ PhD Candidate at the School of Communication, Universiti Sains Malaysia ${ }^{1}$ \\ Lecturer of Communication Department, Universitas Atma Jaya Yogyakarta² \\ \{bonna98@staff.uajy.ac.id¹,niknorma@usm.my²\}
}

\begin{abstract}
Indonesia and Malaysia are neighbouring countries in the Southeast Asian region. The geographical position is the opposite of that in Southeast Asia. However, the number of similarities between the two countries does not necessarily make the relations between the two harmonious. After the 2000s, Indonesia-Malaysia relations often underwent ups and downs. The problem of territorial disputes, cultural claims, migrant workers, as well as the fog due to forest and land fires illustrates the ups and downs of the relations between them. The mass media that have often reported on Indonesia-Malaysia relations included institutions which influenced the perception of the society on Indonesia-Malaysia relations. How the society gives meaning to the relation between the two countries will depend on the integrity of the facts told by the media. This paper attempts to discuss how the media carry out the process of verifying facts in reporting the polemic of the Malaysian national anthem and the song Terang Boelan. This study employed a qualitative analysis using visual social semiotics. The findings of this research show that the Indonesian mass media, in this case, Metro TV and Kompas.Com, still have to put harder attempt to fully present what has happened regarding the polemic between the two songs.
\end{abstract}

Keywords: Journalism; News Production; The Discipline of Verification; Be Skeptical; Functional Truth

\section{Introduction}

Indonesia and Malaysia are two neighbouring countries in Southeast Asia. The close geographical location has caused Indonesia and Malaysia to have many similarities compared to other Southeast Asian countries, such as Thailand, the Philippines, Vietnam, Laos and Cambodia. Some researchers wrote similarities between Malaysia and Indonesia including race, culture, religion, and language. The many similarities make Indonesia-Malaysia believed to be an allied nation [1-2]. The strategic role of the two nations in the economic development of Southeast Asia has been going on for hundreds of years to date [3-7]. 
The many similarities between Indonesia and Malaysia do not always create harmonious relations between the two. Although it never reached a level of an open physical conflict, the two countries were often in tension in the twentieth century. Throughout modern history, the relation between Indonesia and Malaysia have experienced ups and downs. Relations between Indonesia and Malaysia are often in a state of harmony, but not infrequently both experience tension in a certain period [8-10].

Several kinds of research conducted on many Indonesian mass media showed that reporting of events involving the relation between Indonesia and Malaysia was unbalanced. News sources and storylines raised were often taken only from Indonesia's point of view. Other findings in the research also showed that reporting of events involving the relation between the two countries were often presented in a provocative and sensational manner [5][11-14]. Unlike some previous researches, this research explored aspects of the discipline of fact verification which is expected to be done by Indonesian journalists when they report events concerning the relation between Indonesia and Malaysia. Fact verification is an activity of a journalist to not always simply believe news facts received each time a journalism process is carried out [15].

Kovach and Rosenstiel wrote nine codes of conduct that should be well understood and carried out by those who have a strong desire to become journalists [15]. They also stated that one of the important aspects of journalism practices that had to be carried out by journalists in covering news is the discipline of verifying facts [16]. It means that journalists are invited to not easily believe the news facts that have been obtained during the process of producing news. Bigart even said that a journalist was not just a note-taker. Journalists have the responsibility of pursuing facts for themselves, building empirical evidence, and not accepting other people's explanations from the second source. He said that the discipline of verification avoided journalists from rumours, gossip, false memories, and manipulation so that they could obtain accurate and complete facts [16]. The importance of journalists verifying facts in the news production process was because this activity is one of the ethics that they are supposed to carry out. Ethics provides several principles or guidelines for journalists that can be used to decide which actions are right and which actions are wrong, which actions are good and which actions are bad, which actions are responsible and which actions are irresponsible [17].

\section{Method}

The data collection technique in this paper used qualitative content analysis. Content analysis is carried out by conducting an in-depth and structured observation of media texts. By making this observation, the content analysis method can obtain patterns or trends and/or the structure and meaning of media content [18]. The qualitative content analysis approach used was visual social semiotics. Visual social semiotics is the development of MAK Halliday's semiotics and social semiotics. van Leeuwen and Vanini stated that social semiotics is an approach to understanding the meaning of signs used by particular societies [19][20]. In the context of this research, content analysis with a visual social semiotics approach was intended to find out how the two media researched gave meaning to events involving the relation of Indonesia and Malaysia through particular signs. The news studied consisted of five pieces of news, one-piece broadcast by Metro TV and four pieces published by Kompas.Com. 


\section{Result and Discussion}

The polemic of the Malaysian national anthem Negaraku which has similarities to the song Terang Boelan started from the news published by several online news portals and private television stations in Indonesia around the end of 2009. Almost all of the news described that the similarity of the Malaysian national anthem, Negaraku, with one of the Indonesian songs, Terang Boelan, which was popular in the 1950s. The similarity of the two songs lies in the rhythm of the music (the strains of tones) and the tempo of the song. The difference lies only on the lyrics. This similarity led to the alleged plagiarism of the song Terang Boelan to be made into the national anthem of Malaysia Negaraku.

\subsection{Metro TV: (Malaysia) Harassed Indonesia}

Metro TV reported this event with the title Indonesia Dilecehkan (Indonesia is Harassed). The title was written in the form of a passive sentence so that it left an impression that the perpetrator was hidden. The word "harassed" is a signifier which has a signified denotative meaning that Indonesia is being insulted, looked down on, and even ignored (deemed absent) by a certain party. Although Metro TV did not show explicitly who the party that harassed Indonesia was, from the news content, the audience can conclude that Malaysia was the party that was harassing Indonesia. It means that Malaysia was in a position of insulting, looking down on and ignoring Indonesia.

The title of Indonesia Dilecehkan was combined by Metro TV with the picture of the Indonesian red-white flag as a background when the news presenter was reading the news lead. The red-white flag image was a sign in the form of a symbol which meant the national identity of the Indonesian nation. Also, Metro TV used the following sentences as news leads: Viewers, works of art and culture of Indonesia since the 40s, have been taken and utilized by the Malaysian government for their interests. The national anthem Malaysia, Negaraku, for example, bears a resemblance to an Indonesian song entitled Terang Bulan. The only difference is the lyrics of the two songs. These sentences, particularly phrase the phrase since the $40 \mathrm{~s}$ also became a sign in the form of a symbol which brought a meaning that Malaysia had long had a habit of taking the products of Indonesian art and culture. The phrase for their interests in the sentence is a connotative sign that Malaysia had a selfish behaviour which tended to act unilaterally to take and utilize the products of Indonesian art and culture.

The storyline of this news was descriptive and more of a sociological reality. There were only news presenters and news narrators who acted as the tenors of discourse. The absence of interviewees reflected that journalists used observation and documentation research techniques in covering and composing this news. Besides, the body section of the news was presented with a comparative technique by comparing Terang Boelan with the national anthem Malaysia, Negaraku. It was done to certainly emphasize the similarity between the two. Metro TV used these denotative markers to convince the audience that its opinion which stated the similarity between the two songs was not merely emotional. Metro TV sought to present a rational opinion that the similarities of the two songs were true.

Metro TV also presented historical facts in the news body. The historical facts stated that Terang Boelan had existed in Indonesia before 1956. After the song was taken by Malaysia as the national anthem, President Soekarno had appealed that the song would not be sung by the people of Indonesia again. These historical facts had become a sign in the form of an icon as well as a symbol that this song was very old in Indonesia, even older than the age of Malaysia's independence. Metro TV wished to say that Indonesia, not Malaysia, was the 
official owner of Terang Boelan. The figure of President Soekarno displayed by Metro TV also became a symbol that reminded the audience of Indonesia's resistance against Malaysia in the era of Malaysian Confrontation in the 1960s.

These historical facts were supported by a visual display of Metro TV news. It displayed images of song cards that are still neatly stored and handwritten, a list of songs in a book, something like a log book, which is neatly typed, as well as reel ribbons of Terang Boelan that still works. Metro TV also uses the natural sound obtained when the cameraman was covering the event. The natural sound could be heard clearly by the audience when Metro TV compared the Terang Boelan with the national anthem of Malaysia in the state record company Lokananta. The compilation of natural sound with a visual appearance which was ended with musical illustrations to show the comparison between Terang Boelan and the national anthem of Malaysia was a sign that reinforced the message delivered by Metro TV that Terang Boelan was an old song that had been possessed by Indonesia for a long time. It was indicated by the reel tape on the old model audio player displayed by Metro TV. This image became in contrast to the image of a set of modern computer used for playing the Malaysian national anthem, Negaraku. Metro TV intended to say that the age of Negaraku was younger than Terang Boelan. It means that most likely the Malaysian national anthem adapted Terang Boelan. This news section was also strengthened by the subtitle Terang Boelan Sudah Ada Sebelum Malaysia Merdeka.

\subsection{Kompas.Com: Although Terang Boelan was Composed by an Indonesian, People Have to be Cautious in Raising Polemic on the Malaysian National Anthem}

Kompas.Com published four news reports about the polemic of Terang Boelan and the Malaysian national anthem, Negaraku. Two news items on September $1^{\text {st }}, 2009$, namely Lokananta Tidak Somasi Malaysia and Soal Terang Bulan, Kris Biantoro Punya Bukti Hitam Di Atas Putih. Two more reports were published on September $2^{\text {nd }}, 2009$, entitled Lagu Kebangsaan Malaysia Ciptaan Orang Indonesia and Soekarno: Ful, Serahkan Lagu itu ke Malaysia. In contrast to other media that had reported on this polemic since the end of August 2009, Kompas.Com only started this polemic after a few days later, which was in early September 2009. As an online news portal, Kompas.Com did not report this event from the very beginning of the polemic, when some other media had begun to report the similarity of Terang Boelan with the national anthem of Malaysia, Negaraku. Kompas.Com was in the verification phase of the polemic.

The first news Kompas.Com published, which was Lokananta Tidak Somasi Malaysia, informed about the clarification of the state recording company, Lokananta, which did not intend to file a lawsuit against the Malaysian government because of the similarity of the national anthem of Malaysia, Negaraku, with the Indonesian song Terang Boelan. This news was a sign in the form of an index for previous news from other media, which informed about the similarity of the two songs. Lokananta happened to be one of the news sources which was asked about this matter. Signs in the form of indexes were also found in the second news, Soal Terang Bulan, Kris Biantoro Punya Bukti Hitam Di Atas Putih, published on the same day. This news provided information about the warning given by one of the Indonesian artists, Kris Biantoro, who said that the beneficiaries of Terang Boelan would better be careful if they intended to sue the Malaysian government due to the fact that it was actually only a song adapted from a song called Malayan Moon (Bulan Malaya) composed by Paul Lombard, a British or American citizen. This historical fact was also a sign in the form of an index for the history of Terang Boelan. 
The third and fourth news published by Kompas.Com were Lagu Kebangsaan Malaysia Ciptaan Orang Indonesia and Soekarno: Ful, Serahkan Lagu Itu ke Malaysia. Both reports were another form of verification as well as a sign in the form of an index. Kompas.Com tried to trace the source of the news that claimed to be the family of the composer of Terang Boelan. Kompas.Com managed to meet Aden Bahri, the son of Syaiful Bahri, the person who composed the song. Besides, Kompas.Com was able to find another news source, namely Soebroto, a colleague of Syaiful Bahri from the Orkes Radio Djakarta. Soebroto claimed to be a witness to a meeting between the Indonesian President, Soekarno, and Syaiful Bahri at the commemoration of Indonesian Independence Day in 1961 or 1962. President Soekarno asked Syaiful Bahri to give Terang Boelan to Malaysia so that they used it as their national anthem.

Through the four news reports presented, Kompas.Com did not immediately believe that the Malaysian national anthem was an adaptation of Terang Boelan. It was showed by Kompas.Com by narrating a few signs. The first sign was when reporting Lokananta who did not intend to sue the Malaysian government in the first news. It showed that Kompas.Com, through Lokananta, was actually in a position of being not sure that the Malaysian national anthem was an adaptation and even a plagiarization of Terang Boelan. The second, Kompas.Com did not immediately believe that the Syaiful Bahri family was the beneficiary of Terang Boelan. It appeared at the end of the first report. Kompas.Com wrote: "Mengenai pengakuan pihak keluarga Syaiful Bahri yang mengaku bahwa lagu Terang Boelan adalah ciptaan Syaiful Bahri, .... " (In regard to the assertion of the Syaiful Bahri family who claimed that Terang Boelan was the composition of Syaiful Bahri, ....". The phrases who claimed in that sentence showed that Kompas.Com did not directly believe this fact).

The third sign was when telling that Kris Biantoro had legal evidence in the form of a phonograph record of Malayan Moon composed by Paul Lombard in the second news. The tone or rhythm of Malayan Moon was also similar to Terang Boelan. Kris Biantoro also said that Terang Boelan was a very old song because it had been played since 1936. It means that the argument that Syaiful Bahri was the composer of Terang Boelan was open to debate. The fourth, and the last, sign was the absence of other sources as convincing news sources. It was evident from Soebroto's statement who stated that he could no longer remember any other witnesses who listened to President Soekarno's statement when asking Syaiful Bahri to give Terang Boelan to be used as the Malaysian national anthem.

These four signs were symbols used by Kompas.Com to remind people that anyone needed to be careful when raising polemic about the Malaysian national anthem, Negaraku, and Terang Boelan. This is because there were many facts, including historical facts, which were circulating along with the polemic. The public was expected not to easily believe just one or two facts and then drew a conclusion. These facts still needed to be clarified as reliable facts. It needed to be done especially with regards to the relation between the two countries, Indonesia and Malaysia. When it is very easy for people to believe in one or two facts and quickly draw a conclusion, the result can embarrass themselves, as well as Indonesia before Malaysia and the international society.

\subsection{The Discipline of Verification to Present the Functional Truth}

Previous media research on news of relations between Indonesia and Malaysia often placed Malaysia in an unequal position. An unequal position has implications for negative news frames in Malaysia. Some researchers stated that the lack of or even lack of speakers from Malaysia caused the news to be harmful for the Malaysian side in the Indonesian mass media studied. The news sources used by the Indonesian mass media are dominantly sourced 
from Indonesia and more representative of Indonesian interests [11][12]. Besides, several other researchers found the facts that the negative nuance for Malaysia occurred because there were sensational and provocative factors that were deliberately built by the Indonesian mass media to construct the news. For television news, sensationally and provocative not only appear in verbal form in the choice of words used. This sensationally and provocative appear on non-verbal aspects in the form of voice intonation from presenters and reporters when narrating the news, image choices, and musical or song illustrations used to accompany the news narrative [13][14]. Dunan and Adnan also stated that ideological factors in the form of a sense of nationalism and patriotism in routine news production and elements of media ownership in Indonesia reinforced the unfavourable position of Malaysia in the Indonesian mass media news. They also said that the capitalisation of news as an industrial product helped worsen the image of Malaysia in the Indonesian mass media. This means that as a media in Indonesia, it is natural that the interests being defended are those of Indonesia [12].

Different from previous researches, this article tries to look at the discipline of verification aspects of the news about the polemic of the national anthem Malaysia (Negaraku) with the song Terang Boelan from Indonesia. The essence of journalism is the discipline of verification [15]. Based on the definition of the disciplne of verification [16], it seems that Metro TV had not moved further in verifying the facts. The facts reported were purely about the similarity of the Malaysian national anthem to Terang Boelan. These facts were obtained from the results of coverage of the Lokananta state recording company in Solo - Central Java. These facts had also been immediately concluded as the actions of Malaysia to take and utilize Indonesian artwork for unilateral interests of Malaysia. There is no other part of this news or subsequent news that described the event more fully or holistically to inform people about what happened between the Malaysian national anthem and Terang Boelan. As a result, Metro TV news left an impression of an arrogant and selfish attitude of Malaysia towards Indonesia. The meaning generated by Metro TV news finally showed that Malaysia was harassing Indonesia.

In the case of Kompas.Com, there were further efforts done by Kompas.Com to provide a more holistic understanding of the polemic of the Malaysian national anthem. It could be seen from the variety of sources featured in the news. The meaning of Kompas.Com news was different from that broadcast by Metro TV. Kompas.Com was more nuanced to invite the public to be more careful in raising polemic of the Malaysian national anthem and Terang Boelan because Kompas.Com saw that there were many stories or news facts that surrounded the polemic of the two songs. Even the facts of this news still needed to be tested and clarified to be trusted.

\section{Conclusion}

The discipline of verification in the process of producing news is an ethical obligation for journalists and media institutions. Verification discipline is the activity of journalists and media institutions who always question the truth and validity of news facts obtained in the news production process. Journalists and media agencies must be sceptical about any news acquisition. Metro TV does not seem to go further to verify the facts. Metro TV described several shows about the similarity between the national anthem Malaysia (Negaraku) with the Indonesian song Terang Boelan. Metro TV shows the similarity of these two songs directly. Metro TV also got the fact that Radio Republik Indonesia had recorded this song in 1956 or one year before Malaysia gained independence in 1957. Based on these facts, Metro TV immediately concluded that Malaysia unilaterally used the work of Indonesian children for the 
benefit of Malaysia. Metro TV means that Malaysia is harassing Indonesia because of this incident. Kompas.Com looks cautious when reporting the similarity of the events of these two songs. Kompas TV seems to be trying to trace the facts related to these two songs. Because this event is a past event, Kompas.Com conducted many interviews with several speakers called the Terang Boelan song from Indonesia. Kompas.Com interpreted this event as an attempt to remind Indonesians not to rush to accuse Malaysia of using Indonesian children's work as the national anthem of Malaysia.

\section{Acknowledgement}

Thank you to Universitas Atma Jaya Yogyakarta for funding this research and to Universiti Sains Malaysia (Penang) for supporting my presentation at the International Communication Association (ICA) Regional Conference in Bali (Indonesia), October, 16-18 2019.

\section{References}

[1] C. Kremer. "Sourced from Nations Online Project Malaysia and Nusantara Heritage in the Adik-Abang Relationship". Stanford J Int Relations, Vol. 13, No. 2, pp. 28-9, 2011.

[2] A.N. Yaakub. Malaysia and Indonesia: A Study of Foreign Policies with Special Reference to Bilateral Relations. University of Western Australia, 2009.

[3] M. Clarks, J. Pietcsh. Indonesia-Malaysia Relations, Cultural Heritage, Politics, and Labour Migrations. New York: Routledge, 2014.

[4] R.H. Ab Ghani, Z. Paidi. "Malaysia-Indonesia: Pengalaman Hubungan Dua Negara Serumpun." Seminar on National Resilience, p. 223-46, 2011.

[5] B.L.S.W. Wardhani. "Trends in Indonesia-Malaysia Bilateral Relations in Post-Suharto Period." Indones J Soc Sci. Vol. 1, No. 1, pp. 1-9, 2008.

[6] J.C. Liow. The Kinship Factors in International Relations: Kinship, Identity Construction, and Nation Formation in Indonesia-Malaysia Relations. LSE University of London, 2003.

[7] F. Holst F. (Dis-)Connected History: The Indonesia-Malaysia Relationship. In E. Streifeneder, A. Missbach (Eds.). Indonesia-The Presence of the Past A festschrift in honour of Ingrid Wessel [Internet]. Berlin: Regiospectra, p. 327-40. Available from: http://www.regiospectra.com, 2007.

[8] O. Ongge. The Dynamics of Indonesia-Malaysia Bilateral Relations Since Independence: Its Impact on Bilateral and Regional Stability. Asian Conference on Asian Studies, 2015.

[9] M.N. Mat Yazid. Indonesia-Malaysia Relations Before and After 1965, Impact on Regional and Regional Stability. Symposium on Cultural Diplomacy in the Asia Pacific, 2013.

[10] A. Dwijayanto. Hubungan Kebudayaan Indonesia dan Malaysia: Sejarah dan Perkembangan Reyog Ponorogo ke Batu Pahat Johor. In: Proceeding 8th International Conference of Malaysia-Indonesia Relations, 2014.

[11] S. Zabedah, M. Shariff, H. Amelia, A. Aziz. "An Analysis on ASEAN Print Media Coverage: A Case Study on the phenomenon of strife between Malaysia and Indonesia". Int J Humanit Soc Sci, Vol. 2, No. 23, pp. 100-12, 2012. 
[12] M.A. Hamedi, A. Dunan. "Framing Malaysia in the News Coverage of Indonesian Television." Mediterr J Soc Sci. Vol. 7, No. 2, pp. 45-51, 2016.

[13] D. Parahita. "Tari Pendet News on Metro TV in 2009: Reviving National Sentiment." $J$ Mass Commun Journal. Vol. 3, No. 1, pp. 1-8, 2013. 